\title{
Transcriptional regulation of mononuclear phagocyte development
}

\author{
Roxane Tussiwand ${ }^{1 *}$ and Emmanuel L. Gautier ${ }^{2}$ \\ 'Department of Biomedicine, University of Basel, Basel, Switzerland, ${ }^{2}$ INSERM UMR_S 1166, Sorbonne Universités, UPMC \\ Univ Paris 06, Pitié-Salpêtrière Hospital, Paris, France
}

Mononuclear phagocytes (MP) are a quite unique subset of hematopoietic cells, which comprise dendritic cells (DC), monocytes as well as monocyte-derived and tissue-resident macrophages. These cells are extremely diverse with regard to their origin, their phenotype as well as their function. Developmentally, DC and monocytes are constantly replenished from a bone marrow hematopoietic progenitor. The ontogeny of macrophages is more complex and is temporally linked and specified by the organ where they reside, occurring early during embryonic or perinatal life. The functional heterogeneity of MPs is certainly a consequence of the tissue of residence and also reflects the diverse ontogeny of the subsets. In this review, we will highlight the developmental pathways of murine MP,

OPEN ACCESS

Edited by:

Martin Guilliams,

Ghent University, Belgium

Reviewed by:

Elodie Segura,

Institut Curie, France

Vuk Cerovic,

RWTH Aachen, Germany

*Correspondence:

Roxane Tussiwand r.tussiwand@unibas.ch

Specialty section: This article was submitted to Antigen Presenting Cell Biology, a section of the journal Frontiers in Immunology

Received: 15 April 2015 Accepted: 02 October 2015 Published: 19 October 2015

Citation:

Tussiwand R and Gautier EL (2015)

Transcriptional regulation of mononuclear phagocyte development.

Front. Immunol. 6:533. doi: 10.3389/fimmu.2015.00533 with a particular emphasis on the transcriptional factors that regulate their development and function. Finally, we will discuss and point out open questions in the field.

Keywords: transcription factors, development, dendritic cells, macrophages, immunity

\section{INTRODUCTION}

The mononuclear-phagocyte system (MPS), which comprises dendritic cells (DCs), macrophages, and monocytes, is a heterogeneous group of myeloid cells. The complexity of the MPS is equally reflected by the plasticity in function and phenotype that characterizes each subset depending on their location and activation state. Specialized subsets of mononuclear phagocytes (MP) reside in defined anatomical locations, are critical for the homeostatic maintenance of tissues, and provide the link between innate and adaptive immune responses during infections. The ability of MP to maintain or to induce the correct tolerogenic or inflammatory milieu also resides in their complex subset specialization. Such subset heterogeneity is obtained through lineage diversification and specification, which is controlled by defined transcriptional networks and programs. Understanding the MP biology means to define their transcriptional signature, which is required during lineage commitment, and which characterizes each subset's features. This review will focus on the transcriptional regulation of the MPS; in particular, what determines lineage commitment and functional identity; we will emphasize recent advances in the field of single-cell analysis and highlight unresolved questions in the field.

\section{THE MONONUCLEAR-PHAGOCYTE SYSTEM NETWORK}

As summarized in Table 1, the MPS is a rather heterogeneous group of myeloid cells, which includes DC, monocytes, and macrophages (1). DCs are mostly short lived and characterized by a half-life that varies between few days up to few weeks (2). This subset of MPs is equipped with pattern recognition receptors (PRR) and is specialized in antigen capture and presentation to T cells (3). At least three different DC 
subsets have been identified: plasmacytoid DCs (pDCs), and two common or conventional DC (cDC) subsets; cDC1, which express $\mathrm{CD} 24$, and $\mathrm{CD} 8 \alpha$ in lymphoid tissues, or CD103 in peripheral organs; and cDC2, which express CD4, CD11b, and CD172 (1). This latter subset of cDCs is heterogeneous and seems to comprise also monocyte-derived DCs and activated macrophages, which have acquired a DC phenotype and most likely function (4).

Steady-state monocytes are short-lived MPs. They are subdivided into two major subsets: patrolling and inflammatory monocytes, which are characterized by low and high expression of Ly-6C, respectively (5). Inflammatory monocytes are recruited and extravasate into infected tissues. They play a role in maintaining the correct inflammatory milieu, are important in the resolution of inflammation and in certain tissues monocytes will replenish the pool of resident macrophages (5-7). The role of patrolling monocytes is less clear but they are certainly involved in the homeostasis of the endothelium $(8,9)$.

The last subset of MP comprises the mostly long-lived tissueresident macrophages (10). This subset is present in every developing as well as mature tissue, which is highly heterogeneous in terms of phenotype and function, reflecting the physiological needs of the organ of origin (11). Macrophages are thought to be required for the correct development and maintenance of tissues. This topological-related feature is possibly the reason for their extreme heterogeneity and their tissue specialization (12).

Collectively, MPs are highly plastic myeloid cells, which can perform very diverse functions. Table 1 summarizes the mostly used surface markers in mice and the function attributed to the different MP subsets.

\section{TRANSCRIPTIONAL REGULATION OF DENDRITIC CELLS DEVELOPMENT}

As shown in Figure 1, lineage development of hematopoietic progenitor cells along DC lineage occurs through an orchestrated expression pattern of transcription factors (TF), yet the precise molecular mechanisms of lineage restriction and determination remains largely unexplained $(2,13-17)$. The analysis of genetargeted mice has revealed the functional importance of a few

TABLE 1 | Summarized are the three major murine MPs: dendritic cells, monocytes, and macrophages.

\begin{tabular}{|c|c|c|c|}
\hline MPs & Subset & Surface MK & Functions \\
\hline \multirow[t]{3}{*}{ Dendritic cells } & pDCs & SiglecH, Bst2 & $\begin{array}{l}\text { Production of type } 1 \text { IFN } \\
\text { (antiviral response) }\end{array}$ \\
\hline & cDC1 & $\begin{array}{l}\text { XCR1, CD103/ } \\
\text { CD8, Clec9a }\end{array}$ & $\begin{array}{l}\text { Th1 and CTL immunity, cross- } \\
\text { presentation, IL-12 production }\end{array}$ \\
\hline & cDC2 & CD11b, Sirp- $\alpha$ & $\begin{array}{l}\text { Th2 and Th17 immunity, } \\
\text { production of IL-23 and IL-6 }\end{array}$ \\
\hline \multirow[t]{2}{*}{ Monocytes } & $\begin{array}{l}\text { Ly6C high } \\
\text { inflammatory }\end{array}$ & $\begin{array}{l}\text { Ly6C hi CCR2 } \\
\text { hi }\end{array}$ & $\begin{array}{l}\text { Differentiate into DCs and } \\
\text { tissue macrophages during } \\
\text { inflammation }\end{array}$ \\
\hline & $\begin{array}{l}\text { Ly6C low } \\
\text { patrolling }\end{array}$ & $\begin{array}{l}\text { Ly6C low CCR2 } \\
\text { low Cx3Cr1 }\end{array}$ & Endothelial integrity \\
\hline Macrophages & $\begin{array}{l}\text { Tissue } \\
\text { specific }\end{array}$ & $\begin{array}{l}\text { F4/80, MerTK, } \\
\text { CD64 CD11b }\end{array}$ & Tissue specific \\
\hline
\end{tabular}

Each MP subset can be further subdivided into different subsets based on surface marker expression and function and as indicated. critical TFs in DC development, with some of them affecting all DCs and some affecting specific subsets (18). DC progenitors are present within the fms-related tyrosine kinase 3 (Flt3)-expressing bone marrow fraction and sustained Flt3 signaling can be considered as instructive for DC development (19-22). Consistently, Flt3-ligand (Flt3L) supports the in vitro differentiation of progenitor cells into both pDCs and cDCs $(23,24)$. Genetic deletion of Flt3L, its receptor, or treatment of mice with Flt3 inhibitors leads to a 10 -fold reduction of lymphoid-organ pDCs and cDCs (25, 26). Moreover, Flt3L injection or overexpression of Flt3L results in the expansion of both pDCs and cDCs in all lymphoid and non-lymphoid organs $(27,28)$. Engagement of Flt3 by Flt3L induces Stat3 phosphorylation and activation, identifying Stat3 as the critical checkpoint of Flt3-induced DC development and proliferation $(29,30)$. Mirroring Flt3 deficiency, Stat3-deficient mice have severely reduced DC progenitors and mature cells (29). Similarly, deletion of the transcriptional repressor growth factor independent 1 (Gfil) results in impaired DC development (31). Gfil-deficient mice show reduced Stat3 phosphorylation and nuclear translocation, with increased expression levels of the Stat3 negative regulators SOCS3 and PIAS3 suggesting that Gfi1 is downstream of Stat3 signaling in the Flt3-Flt3L-induced DC developmental pathway (31). However, the role of Gfil is more complex since mice deficient for this repressor show multiple hematopoietic impairments $(32,33)$. The defects related to Gfil deficiency can partially be related to dysregulation of Id 2 expression (34-36). However, further studies using subset-specific deletion models will be instrumental to precisely dissect specific transcriptional requirements within the MP lineage. Similarly, despite the experimental evidence of DC expansion following sustained Flt3 signaling, the instructive mechanism promoting DC development is still unclear, given the broad expression of Flt3 on all short-term uncommitted hematopoietic progenitors (ST-HSC) $(37,38)$. A long non-coding RNA (lncRNA), named lnc-DC, was recently suggested to be the missing key element regulating Stat 3 activity exclusively in DCs (39). lnc-DC RNA is expressed by mature DCs and by monocyte-derived DCs and seems to directly interact with Stat3 preventing its de-phosphorylation by SHP1. Furthermore, knockdown experiments of lnc-DC in vitro showed impaired DC development from mouse BM progenitors. The conservation of this lnc-DC in terms of function and of its consensus elements at the promoter region across species supports the hypothesis of a new level of regulation present in DC development. However, in mice the transcript seems translated into a highly expressed protein in adipose tissue (40). Further studies are therefore needed to understand potential species-specificities as well as its requirement in vivo under steady-state conditions.

Proceeding along the DC developmental pathway, three major branches of mature DCs are identified: pDCs, CD24 $4^{+} \mathrm{cDC} 1$, and $\mathrm{CD}_{11} \mathrm{~b}^{+} \mathrm{cDC} 2(3,16)$. pDCs and $\mathrm{cDC} 1$ both express and depend on the transcription factor interferon regulatory factor 8 (Irf8), while cDC2 express and are partially dependent on Irf4 $(1,18,41-44)$. Despite major advances in our understanding of the transcriptional requirement during DC development, we are still unable to draw a clear developmental map (Figure 2) (13, 18). This may reflect subset heterogeneity as well as the plasticity, which characterizes DCs. Also, the expression of the different TFs 


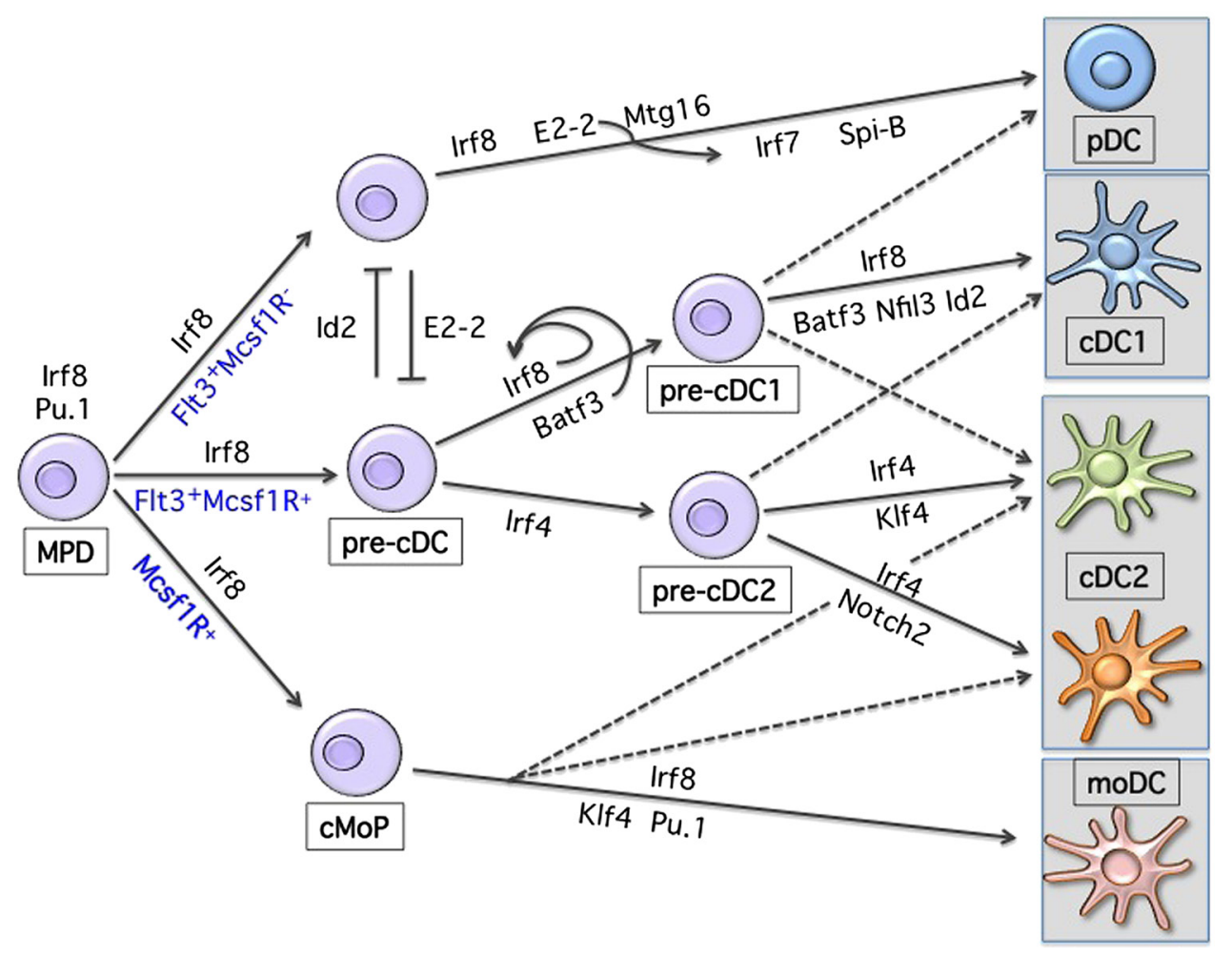

FIGURE 1 | Transcriptional development of dendritic cells. Shown are the major transcription factors known to be involved in DC lineage commitment. Development occurs from a Flt3-, Irf8-expressing hematopoietic progenitor. Progressive acquisition of one or more TFs will result in differentiation toward a specific MP subset. Loss or reduction of one or more TFs can, to some extent, redirect commitment to another lineage.

is not unique and can change during differentiation and activation further complicating the picture.

During early stages of DC development, a progenitor that expresses high levels of Irf8 and shows developmental potential toward all DCs can be identified (42). It is likely that the first branching choice will determine whether pDCs or $\mathrm{CDCs}$ commitment occurs. The balance of the E-protein transcription factor 4 (Tcf4), also known as E2-2, and the E-protein inhibitor of DNA binding 2 (Id2) seems to determine lineage development toward pDCs or cDCs, respectively (45-50). Constitutive or inducible deletion of E2-2 in CD11c-expressing cells blocks the development of pDCs but not cDCs, while overexpression of Id 2 inhibits $\mathrm{pDC}$ development $(47,48)$. E2-2 is required not only during development but also for lineage maintenance of pDCs $(47,51)$. Several targets of E2-2 have been identified such as SpiB, Irf8, and Irf7, and all contribute to pDCs lineage specification $(47,51)$. Despite the requirement for E2-2 during pDCs commitment, how Id 2 and E2-2 are conversely induced and regulated is still an open question. Recently, the eight-twenty-one (ETO) protein 2 or Mtg16 (also referred as core-binding factor, runt domain, alpha subunit 2, translocated to $3 \mathrm{Cbfa} 2 \mathrm{t} 3$ ) was suggested to target and repress Id2 together with E2-2 and inhibit Irf8-expressing cDC1 development, while favoring pDC commitment (52). Consistently, Id 2 and Mtg16 double-deficient mice show restored pDC potential (52). However, Mtg16 seems to act together with E2-2 leaving the question on how lineage determination toward E2-2- or Id2-expressing progenitors occurs, still open. On the other side, one other candidate, which could be involved in reinforcing lineage fate toward Irf8-expressing $\mathrm{CDC} 1$ at the expenses of $\mathrm{pDC}$ could be the leucine zipper transcription factor E4BP4, also referred as Nfil3 (53). Mice deficient for this TF show increased $\mathrm{pDC}$ and reduced $\mathrm{CDC} 1$ development (53). The mechanism of action remains to be elucidated since Id 2 expression does not appear to be perturbed and only the basic leucine zipper transcription factor ATF-like 3 (Batf3) expression was shown to be reduced (53). Phenotypically, a bias toward pDC development has been observed within the macrophage-colony-stimulating factor receptor (M-CSFR) negative progenitors, whereas $\mathrm{CDCs}$ precursors are enriched within the M-CSFR expressing BM fraction $(54,55)$. These results may suggest that under sustained M-CSF stimulation uncommitted progenitors may lose the potential toward pDCs. Alternatively, as recently suggested, the absence of GM-CSF signaling, which induces STAT5 phosphorylation, could be the permissive condition to promote pDC development (56). Accumulation and/or withdrawal of specific cytokines during proliferation and differentiation as well as regulation of TF levels through division of progenitor cells could partially explain how BM niches influence development and lineage commitment $(57,58)$.

Proceeding along DC development, a common cDC progenitor able to differentiate in vivo into both $\mathrm{CD} 24^{+} \mathrm{cDC} 1$ and $\mathrm{CD}_{11} \mathrm{~b}^{+} \mathrm{cDC} 2$ was identified $(55,59-61)$. And recently, lineagetracing studies allowed further dissection of $\mathrm{cDC}$ commitment and resulted fundamental to establish the transcriptional 


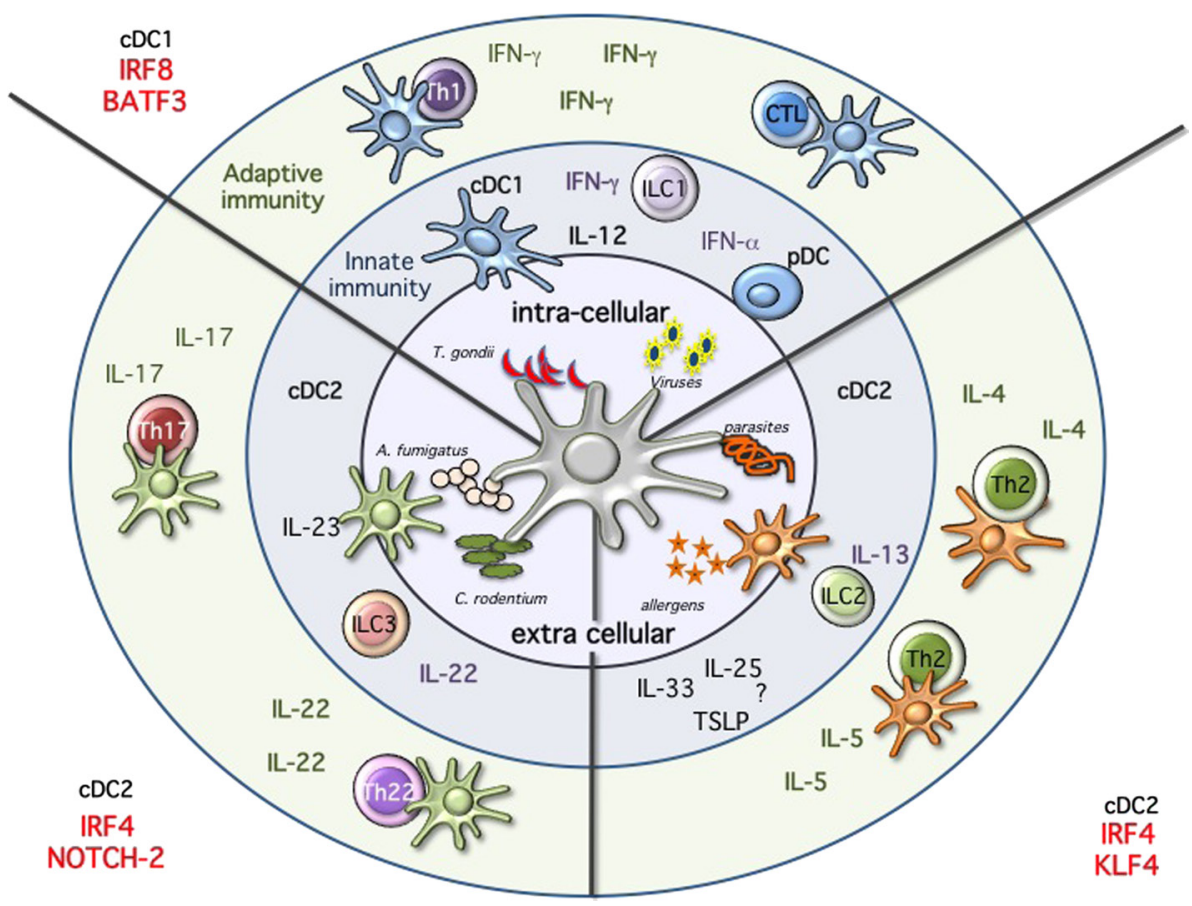

FIGURE 2 | Immune modules dendritic cells will sense the environment and start the immune response by producing cytokines, activating innate immune cells, and priming T cells. Intracellular pathogens, such as Toxoplasma gondii, or viral infections will activate cDC1 and pDCs. These subsets are specialized in the production of IL-12 and type 1 IFNs, respectively. High amounts of IL-12 will activate innate lymphoid cells 1 (ILC1) to produce IFN-g and ultimately leading to the priming of Th1 immunity and sustain IFN-g secretion. Following viral infections, pDCs will produce high amounts of type 1 IFNs, while cDC1 will prime CTL response through cross-presentation of infected cells. Immunity against fungi and extracellular pathogens is mostly mediated by Irf4/Notch2 cDC2, which produce high amounts of IL-23, leading to the activation of ILC3 and IL-22 production as well as priming of Th17 and Th22 T cells. Th2 immunity during allergic reactions and following parasitic infections requires KLf4-dependent CDC2. In this case, the mechanism seems to be more complex and may require ILC2, but ultimately results in the activation of Th2 cells and the production of IL-4 and IL-5.

requirements during development of clonogenic $\mathrm{cDC}$ progenitors $(62,63)$. The expression pattern of the zinc finger and BTB domain containing 46 transcription factor Zbtb46 (also called Btbd4) can be considered as cDC-lineage specific within hematopoietic cells (64-66). This TF is not present on pDCs and is induced on monocyte-derived DCs, supporting on the one hand early divergence of pDCs during DC commitment, and on the other hand suggesting a developmental convergence between cDCs and monocyte-derived DCs $(4,66)$. Similarly, lineagetracing experiments were performed using mice expressing Cre recombinase under the control of Clec9a also referred as Dngr-1 (67). Although labeling is not absolute on all cDCs subsets, it seems to be restricted to pre-cDC progeny, without marking inflammatory-derived DCs (67). The use of these reporter mouse models will help us better characterize the ontogeny of specific cDCs subsets also depending on the tissue of origin and whether under steady-state or inflammatory conditions.

The CD24 ${ }^{+}$cDC1 branch of cDCs depends on the transcription factors Irf8, Id2, Nfil3, and Batf3 (68). The generation of mice deficient for Batf3 has revealed the common origin and the lineage identity of Irf8-expressing cDC1 cells, also referred as $\mathrm{CD} \mathrm{a}^{+}$or $\mathrm{CD}_{103}{ }^{+}$across all lymphoid and peripheral organs $(69,70)$. However, while only Irf8 was shown to be necessary for commitment, Id2, Nfil3, and Batf3 are dispensable under certain conditions $(71,72)$. Lineage choice seems influenced by high and sustained levels of Irf8 during cDC1 commitment. Binding of Batf3 and Irf8 to an AP1-IRF composite element (AICE) within the Irf8 super-enhancer in CD24- or Zbtb46-gfp-expressing immediate progenitors leads to sustained Irf8 expression and cDC1 development (62). In the absence of Batf3, reduced Irf8 levels, redirect commitment of a CD24-expressing $\mathrm{CDC} 1$ progenitor toward the Irf4-expressing cDC2 lineage (62).

Despite the recent advances, how the branching of $\mathrm{cDC} 1$ and cDC2 occurs is still an open question. The recent identification of a committed CDC2 progenitor might help to identify the key factors involved in this process: we still need to understand how expression of Irf4 progressively replaces Irf8, and how those two TF determine the identity of these subsets. Furthermore, the cDC2 lineage, as already mentioned, is highly heterogeneous and possibly contains multiple subsets $(1,2,11,16,18)$. Mature CD11b-expressing cDC2 express high levels of Irf4, suggesting an important role for this TF within this lineage. And indeed, absence of Irf4 impairs the development as well as the function of cDC2 $(42,44,73-77)$. In mice lacking IRF4 in CD11c-expressing cells, cDC2 numbers are reduced in lung and small intestinal DCs, while no difference is reported for skin $(44,74)$. However, reduction in lung and lamina propria cDCs is only observed upon deletion of Irf4 in early progenitors $(44 ; 74)$. Despite, normal numbers of skin DCs in Irf4deficient animals, migration to draining lymph nodes is impaired as a consequence of defective induction of CCR7 (78). Furthermore, 
reduced up-regulation of $\mathrm{MHC}$-II and co-stimulatory molecules is also associated with Irf4 deficiency $(75,77,78)$. Collectively, Irf4 shows a broad action across different tissues and potentially subsets, and further studies are required to be able to understand the specific requirement of this TF during development.

Other TFs reported to display a reduction of $\mathrm{CDC} 2$ are RelB, Notch2, RbpJ, and the Kruppel-like Factor 4 (Klf4) (79-85). Notch2 is required for terminal differentiation of endothelial cell-selective adhesion molecule (ESAM)-expressing splenic cDC (81, 83). Similar to Notch2 deficiency, mice compromised in Runx3 (86, 87 ) and in the alternative NF-kB pathway show a reduction in the development of $\mathrm{ESAM}^{+} \mathrm{cDCs}(80,88)$. However, a survival disadvantage in competitive settings appears to be present in mice with compromised NF-kB signaling, suggesting caution in proposing the requirement for NF-kB during DCs development $(80,88)$. Klf4 deficiency results in impaired development of the so-called "double negative" DCs in skin draining LN and a partial reduction of Sirp- $\alpha$ but not splenic ESAM-expressing cDC2 across all the organs (84). In these mice, $\mathrm{CDC}$ progenitors are impaired in their ability to down-regulate Irf8 and up-regulate Irf4. However, the in vitro differentiation potential of Irf4-expressing $\mathrm{cDCs}$ as well as expression of Irf4 on peripheral cDCs is not compromised. This can be explained by the existence of at least two $\mathrm{CDC} 2$ subsets, where only the Klf4/Irf4-dependent one is developmentally impaired. Alternatively, a different maturation/activation state, which requires Klf4, may exist within the Irf4-expressing cDC2 subset.

Collectively, a partial reduction associated with the lack of one or the other TF confirms the developmental, and supports the subset-specific heterogeneity observed in single-cell sequencing experiments for the Irf4 and CD11b-expressing cDC2 cells (8992). The transcriptional diversity, which characterizes these $\mathrm{cDC} 2$ cells, results and reflects a functional heterogeneity (Figure 2). Notch2 cDC2 are required for anti bacterial Th17/IL-22 immunity, while Klf4 deficiency results in impaired Th2 immunity (83, 84, 93). Expression of Irf4 in cDCs is necessary for both Th17 and Th2 responses further highlighting the complexity of this TF in DC biology $(44,73,74,77)$. Understanding whether the absence of a subset or a functional defect caused by a transcriptional deficiency on the remaining subset could account for the observed phenotypes will require subset-specific deletion. Furthermore, we also need to explore more in detail the influence of tissues on the different subsets. Are tissue-specific cues driving the expression of a transcriptional signature in a similar way as recently revealed for macrophages? (12) Are the differences reflecting a developmental or a functional heterogeneity? Is a developmental convergence between $\mathrm{cDCs}$ and monocyte-derived DCs creating the confusion within this branch of cDCs. We need a better characterization of the different subsets, which fall under the broad umbrella of CD11b or Irf4-expressing cDC2 and some progress has certainly been made with the introduction of new reporter mice as previously discussed as well as the recently identified committed progenitor. Teasing this heterogeneous pool of Irf4-expressing cDC2 apart is currently an active field of investigation (90, 91, 94). And new technologies will be instrumental to improve our comprehension of the molecular clues, which regulate lineage commitment. A recent report analyzed stage and subset-specific expression of mi-RNAs during DC development and miR-142 was identified as a key regulator of $\mathrm{cDC} 2$ differentiation, further adding additional complexity to our current understanding of DC development (91).

Better genetic models are needed and will possibly be soon developed as a result of the recently published single-cell analysis $(16,89)$. Identifying TFs or surface markers, which would compromise or trace the development of one lineage independently of the anatomical localization, as previously done in Batf $3^{-/}$mice for Irf8-dependent $\mathrm{CDC} 1$ would be of great advantage $(69,70)$.

\section{TRANSCRIPTIONAL REGULATION OF MONOCYTE DEVELOPMENT}

The molecular regulation, which defines monocyte differentiation and lineage commitment, is poorly understood (95). Most of the identified TFs, that result in impaired monocyte development, also show an effect on other hematopoietic lineages. The transcription factors Irf8, Sfpi1 (PU.1), Egr-1, Stat3, Gfi1, Gata2, Gbx2, Nur77, retinoic acid receptors, $\mathrm{C} / \mathrm{EBP} \alpha$ and $\mathrm{C} / \mathrm{EBP} \beta, \mathrm{Klf} 4$, and $\mathrm{c}-\mathrm{Maf}$ as well as members of the NF- $\kappa \mathrm{B}$ family members are all involved in monocyte differentiation, however their function is often redundant, certainly not limited to monocytes and in some cases mediating proliferative and/or survival rather than instructive cues (96). Most of the TFs involved in monocyte differentiation are shared within the myelo-monocytic branch. Some of them were already mentioned as important during DC development; others are involved in macrophage and or granulocyte commitment; we are therefore aware that we can only provide here a simplified transcriptional path, which leads to monocyte development and that more efforts are required to better understand.

Expression of the ETS family transcription factor Sfpil or PU.1 at early stages is suggested to antagonize on the one hand key regulators of other developmental pathways, such as GATA-1 for erythroid lineage, and on the other hand activate myeloid-specific factors such as Irf8, Klf4, and Erg1 (95). A critical step in monocyte differentiation is the induction of Csf1R expression at the cell surface. This seems to be regulated by Klf4 and Irf8, however both factors are also involved in cDC development, as previously discussed, (85). Furthermore, Csf1R is also needed for macrophage development.

The identification of a committed progenitor with monocyterestricted potential called cMoP confirmed high expression levels of the above-mentioned TF (97). However, none of those is unique to monocyte differentiation and potentially complex genetic models will be required to unravel the transcriptional map required for monocyte lineage specification.

\section{ORIGIN OF TISSUE-RESIDENT MACROPHAGES}

As discussed above for DCs, similar questions arise considering tissue-resident macrophage origin and development. Lineagetracing studies recently revisited their origin and revealed how their maintenance in adult tissues is mostly independent from monocytes and adult definitive hematopoiesis (10). Indeed, tissue-resident macrophages were proposed to develop from a Myb-independent but Sfpi1 (PU.1)-dependent fetal progenitor present in the yolk sac (YS) $(5,6,15,98-100)$ and capable of seeding the developing embryo 
and self-renewing during adulthood. This developmental path was first described for microglia, the brain-resident macrophages (98, 99), but still remained elusive for a number of other macrophage populations. Using similar tools, the contribution of YS progenitors to a number of adult tissue-resident macrophage populations was next assessed and only very limited input was found in most tissues tested (101). In parallel, other studies conducted in the lung and skin found that resident alveolar macrophages and Langerhans cells originated from fetal monocytes $(99,102)$. A recently described hypothesis is now trying to bridge these findings by proposing the existence of erythro-myeloid progenitors (EMP) distinct from hematopoietic stem cells (HSCs), which develop in YS (E8.5) and colonize the fetal liver at E16.5 giving rise to fetal erythrocytes, macrophages, granulocytes, and monocyte $(103,104)$. Such progenitors would generate microglia early during fetal development and participate to Kupffer cells and Langerhans cells development, but its definitive participation to the generation of other tissue-resident populations, as well as its long-term persistence, still remains to be firmly established. Indeed, a very recent study is now arguing that fetal HSCs, and not YS progenitors or EMPs, give rise to most tissue macrophage populations, except microglia known to originate from YS progenitors other than HSCs (105). This study also highlighted that while most tissue macrophages subsets maintain by self-renewal in the adult, peritoneal, dermal, and colonic residents macrophages needed continuous HSCs input to be maintained during lifetime. Accordingly, gut macrophages, most likely a specific population of macrophage residing in the serosa (106), were shown to derive from HSC-derived circulating monocytes (107). Moreover, blood monocytes can participate to the maintenance of heart macrophages in the adult (108). During inflammation, in addition to tissue-resident macrophages, some macrophages found in tissue differentiate from locally recruited Ly-6C ${ }^{\text {hi }}$ monocyte. Such monocyte-derived macrophages reside only for a short period of time in the tissue until inflammation resolves, and are cleared through local cell death (109). Overall, these studies suggest that there is probably more than a single developmental pathway to generate tissue macrophages and to support their self-renewal potential and unique long-term maintenance ability (Figure 3).

\section{PATHWAYS ALLOWING FOR TISSUE- RESIDENT MACROPHAGE DEVELOPMENT AND MAINTENANCE}

Proceeding along development, Runt-related transcription factor 1 (RUNX1) is required at early stages of myeloid lineage specification and regulates the expression of Sfpil (PU.1) which has to be expressed at high levels to allow for development and maintenance of macrophage differentiation (57). One of the most crucial target genes of PU.1 during macrophage development is Csf1r, which encodes the receptor for M-CSF and IL-34 (110). Signaling of M-CSFR through either M-CSF or IL-34 allows for the maintenance of tissue-resident macrophages (111, 112). Other TFs required for macrophage development, which co-operate with PU.1 in lineage determination, are AML1 and CCAAT enhancer-binding proteins (C/EBP) $(113,114)$. Overall, our understanding of the molecular pathways controlling tissue macrophage development in general, as well as their maintenance, remains poorly defined and further studies are need to better characterize how their development is regulated. While for DCs, deletion of a subset might result in minor consequences, macrophages are thought to be critical for the organogenesis and organ homeostasis, therefore deletion of a subset could be deleterious for the life of the individual or only compatible with compensation through alternative subsets or pathways.

\section{TISSUE-RESIDENT MACROPHAGES DIVERSITY AND TISSUE-SPECIFIC TRANSCRIPTION FACTORS CONTROLLING RESIDENT MACROPHAGE
DEVELOPMENT AND MAINTENANCE}

Our analysis of the transcriptional landscape of tissue-resident macrophages revealed wide heterogeneity across tissues, leading to the definition of population-specific signatures. These specific signatures were recently shown to rely on distinct enhancer landscapes shaped by the tissue microenvironment $(115,116)$. Using the Immunological Genome database, the reconstruction of lineage-specific regulation from gene-expression profiles across lineages (117) revealed gene modules selectively associated with a single tissue macrophage population (12). Additionally, TFs were predicted to regulate these modules, and thus could potentially influence the development of resident macrophages in a tissue-specific manner (12). Among others, predicted regulators included Spi-C for red pulp macrophages, which confirmed precedent findings (118) and thus validated the predictive power of the algorithm. Indeed, Spi-C is a TF closely related to Sfpil and highly expressed in spleen red pulp macrophages compared to other phagocytes $(12,118)$. Mice deficient for Spi-C lack splenic red pulp macrophages (118), leading to defective red blood cells recycling and iron accumulation in the spleen. At which levels Spi-C acts to control the differentiation and/or survival of red pulp macrophage remains to be determined. LXR $\alpha$ is another TF needed for splenic red pulp macrophage development (119), and whether Spi-C and LXR $\alpha$ interact together in this process is not known. Interestingly, intracellular heme accumulation following erythrocytes uptake induced Spi-C expression by stimulating the degradation of its transcriptional inhibitor Bach1 (118). Thus, heme-induced Spi-C controls the functionality of splenic red pulp macrophages, but also their maintenance albeit by an undetermined mechanism.

Similarly, PPAR $\gamma$ was identified as a regulator for lung macrophages (120). It is a ligand-controlled TF of the nuclear receptor family known for its role in lipid metabolism (121). Previous work has shown that PPAR $\gamma$ expression is important to maintain lung macrophages functionality and surfactant catabolism (122). We reported that conditional deletion of PPAR $\gamma$ in lung macrophages strikingly altered their transcriptome (120). Dysregulated expression of a number of genes involved in lipid metabolism was observed (120), and many of these genes were known targets of the sterol-responsive transcription factor LXR. Accordingly, increased sterol accumulation was observed in lung macrophages lacking PPAR $\gamma$, as well as decreased expression of genes involved in inflammation and immunity (120). Using a different gene deletion 


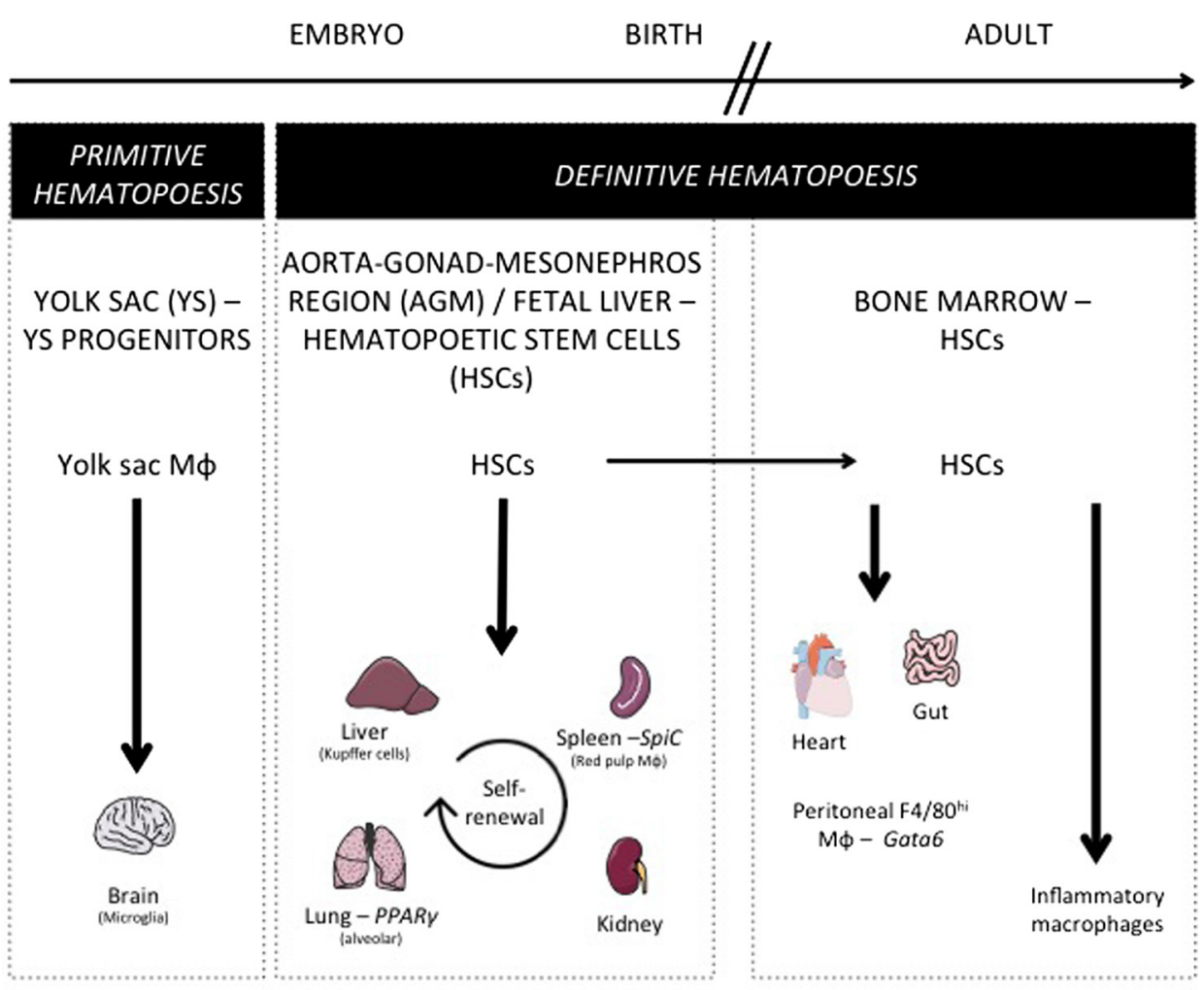

FIGURE 3 | Macrophage ontogeny and requirement on specific transcription factors. This figure shows the progenitors of the different tissue-resident macrophage populations. During embryogenesis, yolk sac progenitors only give rise to microglia. Most tissue-resident macrophages develop before birth and are derived from early hematopoietic stem cells (HSC) present in the aorta-gonad-mesonephros region and in fetal liver. After birth and in the adult mouse, alveolar, splenic, liver, and kidney macrophages maintain their pool by self-renewal, while gut and heart macrophages need a constant replenishment from bone marrow HSC. Additionally, this figure depicts the transcription factors specifically controlling a single resident macrophage population such as Spi-C for splenic red pulp macrophages, PPAR $\gamma$ for alveolar macrophages, and Gata6 for peritoneal F4/80hi macrophages.

approach, it was recently shown that PPAR $\gamma$ could also be key in controlling the development of this subset. Such discrepancy between models might relate to the different temporal induction of the cre expressing strains used in these two studies (123).

Finally, GATA6 was identified as a specific peritoneal macrophage regulator and we observed that its expression was selectively found in $\mathrm{F} 4 / 80+$ peritoneal macrophages across many lineages tested (12), suggesting that it may represent the master regulator of tissue-resident peritoneal macrophages. Interestingly, GATA6 expression by resident peritoneal macrophages was dependent on retinoic acid signaling in vivo (12) and mice lacking GATA6 in macrophages, generated by crossing Gata $6^{\mathrm{f} / \mathrm{fl}}$ mice with Lyz2-cre, showed a strong reduction in F4/80+ peritoneal macrophages (115-117). Additionally, Th2 inflammation following parasitic infection failed to increase peritoneal macrophage numbers in Lyz2-cre $\times$ Gata6 $^{\mathrm{A} / \mathrm{fl}}$ mice (124), as described for wild-type mice (125). Impaired steady-state numbers of peritoneal macrophages in the absence of GATA6 was accompanied by impaired self-renewal, marked increased in S/G2-M cell cycle phases and accumulation of multinucleated macrophages due to impaired cytokinesis (126). While reduced survival of peritoneal macrophage already explains the strong contraction in their number, impaired cytokinesis will likely further exacerbate the phenotype. GATA6 deficiency in $\mathrm{F} 4 / 80+$ peritoneal macrophages led to the down-regulation of Aspa mRNA, which encodes an aspartoacylase generating acetyl-CoA, a central cellular metabolite, from $N$-acetylaspartate (124). Interestingly, mice lacking Aspa showed reduced F4/80+ peritoneal macrophages. Overall, a tissue-specific transcriptional network driven by GATA6 controls multiple pathways all required for the maintenance of $\mathrm{F} 4 / 80+$ peritoneal macrophages.

\section{CONCLUDING REMARKS}

In the past few years, major advances have been made in our understanding how the development of myeloid cells occurs. DNA, RNA protein sequencing and characterization on entire tissues and populations is now a more accessible technology. This combined with improved multicolor flow cytometry and CyTOF technology has allowed us to better understand which TFs identify specific subsets and developmental stages during hematopoietic development (89, $90,124,127)$. However, as it is often the case, the better our analysis tools become, the more complex the picture appears. And despite these advances, we are now starting to perceive how many more gaps need to be filled in order to be able to draw a definitive road map for every MP subset. Significant progress has been made in defining, which TF are needed during DC and macrophage development 
in specific tissues. Monocyte development, however, is still elusive and most of the factors identified rather compromise their survival, making hard to discriminate between developmental and survival defects. Moreover, in the past few years, it has become obvious how tissues are able to influence not only the phenotype but also the function of the different subsets. This observation translates in changes in the transcriptional signature, which identifies each subset in a given tissue. Tissue-associated hallmarks have been mostly studied in macrophages, however profound consequences appear to matter also within DC subsets. It will therefore be important to discriminate between tissue- versus subset-specific transcriptional identity, to define intrinsic properties, and functional potential for every subset across and within the different tissues. On the one hand, it is attractive to think that subset specialization similar as for $\mathrm{T}$ and innate lymphoid cells is also present within the myeloid compartment. On the other hand, we are aware that myeloid cells are characterized by an elevated intrinsic functional plasticity. Anatomical compartments, pathogen and antigen dose as well as small micro-environmental cues might drastically influence the phenotype, the transcriptional landscape as well as the function of the different subsets during immune responses and we are just starting to explore in depth the complexity of the different subset in response to an immunological insult $(90,127)$. For DCs, a model has been recently suggested which takes into account the development of a subset with its immunological function. As shown in Figure 2, expression of Irf8 and Batf3 is needed in response to pathogens or immunological conditions where IFN- $\gamma$ is required. On the other side, Irf4 is essential to stimulate Th17, Th2, and IL-22 responses. Within the Irf4 response, Notch 2 and Klf4 are specifically required for Th17/IL-22 or Th2 immunity, respectively. The scenario, which appears, is consistent with functional modules of transcription across different cell types, i.e., Klf4 is also necessary for goblet cell development and polarization of M2 macrophages, whereas Notch is required for ILC3 development. Similarly, Nfil3 is important not only for $\mathrm{CDC1}$ but also for NK and ILC1 cells development.

Several TFs that are required for MP development have been characterized; we can draw a map for their temporal requirement along development but for most of them the precise mechanism of

\section{REFERENCES}

1. Guilliams M, Ginhoux F, Jakubzick C, Naik SH, Onai N, Schraml BU, et al. Dendritic cells, monocytes and macrophages: a unified nomenclature based on ontogeny. Nat Rev Immunol (2014) 14:571-8. doi:10.1038/nri3712

2. Merad M, Sathe P, Helft J, Miller J, Mortha A. The dendritic cell lineage: ontogeny and function of dendritic cells and their subsets in the steady state and the inflamed setting. Annu Rev Immunol (2013) 31:563-604. doi:10.1146/ annurev-immunol-020711-074950

3. Satpathy AT, Wu X, Albring JC, Murphy KM. Re(de)fining the dendritic cell lineage. Nat Immunol (2012) 13:1145-54. doi:10.1038/ni.2467

4. Schlitzer A, McGovern N, Ginhoux F. Dendritic cells and monocyte-derived cells: two complementary and integrated functional systems. Semin Cell Dev Biol (2015) 41:9-22. doi:10.1016/j.semcdb.2015.03.011

5. Yona S, Kim KW, Wolf Y, Mildner A, Varol D, Breker M, et al. Fate mapping reveals origins and dynamics of monocytes and tissue macrophages under homeostasis. Immunity (2013) 38:79-91. doi:10.1016/j.immuni.2012.12.001

6. Varol C, Yona S, Jung S. Origins and tissue-context-dependent fates of blood monocytes. Immunol Cell Biol (2009) 87:30-8. doi:10.1038/icb.2008.90

7. Zigmond E, Varol C, Farache J, Elmaliah E, Satpathy AT, Friedlander G, et al. Ly6C hi monocytes in the inflamed colon give rise to proinflammatory action and their targets still need to be identified. Furthermore, since the developmental as well as the functional requirements for a transcriptional pathway are most often shared, caution is necessary to ascribe a specific role to a TF. Recently, a Waddington landscape was suggested to explain the plasticity in DC development (92). A similar concept may reflect and be applied to the entire MP system, where lineage commitment, specific functions, as well as subset identity could depend on the achievement of a threshold of a pool of TFs, rather than a unique master regulator. This concept would explain the so-called "graded-commitment" obtained from barcoding individual progenitors and performing lineage-tracing experiments (128). A second level of complexity is characterized by the fact that multiple subsets share the same TF, though the functional requirements are different. For example, Irf4 seems to regulate migration in skin DCs but not in other peripheral tissues, such as lungs. The functional outcome might be shared; such as in both cases antigen presentation is impaired, however it is important to understand the different requirements depending on the tissue of origin.

The study of MP is characterized by blurry phenotypic boundaries, which do not allow for unequivocal identification of the different subsets. The absence of specific markers leads to the absence of specific genetic tools and sometimes conflicting or unclear results are present in the literature. For lineage-specific deletion within $\mathrm{CDC}$, we still relay on $\mathrm{CD} 11 \mathrm{c}$-cre mice, despite the evident limitations of this model. For monocytes as well as macrophages we lack genetic models, which would allow for selective and specific depletion of inflammatory or patrolling monocytes as well as tissue macrophages. Efforts to generate better lineagedeleter mouse models are therefore required and should be a priority in the next future to better understand the development as well as the contribution of MPs during an immune response.

\section{ACKNOWLEDGMENTS}

RT is supported by the Swiss National Fund with an SNF Professorship (NBM 1570). EG is funded by grants (LIPOCAMD and MACLEAR) from the National Agency of Research (ANR) and by a grant from the Fondation de France (00056835).

effector cells and migratory antigen-presenting cells. Immunity (2012) 37:1076-90. doi:10.1016/j.immuni.2012.08.026

8. Geissmann F, Auffray C, Palframan R, Wirrig C, Ciocca A, Campisi L, et al. Blood monocytes: distinct subsets, how they relate to dendritic cells, and their possible roles in the regulation of T-cell responses. Immunol Cell Biol (2008) 86:398-408. doi:10.1038/icb.2008.19

9. Auffray C, Fogg D, Garfa M, Elain G, Join-Lambert O, Kayal S, et al. Monitoring of blood vessels and tissues by a population of monocytes with patrolling behavior. Science (2007) 317:666-70. doi:10.1126/ science. 1142883

10. Hashimoto D, Chow A, Noizat C, Teo P, Beasley MB, Leboeuf M, et al. Tissue-resident macrophages self-maintain locally throughout adult life with minimal contribution from circulating monocytes. Immunity (2013) 38:792-804. doi:10.1016/j.immuni.2013.04.004

11. Malissen B, Tamoutounour S, Henri S. The origins and functions of dendritic cells and macrophages in the skin. Nat Rev Immunol (2014) 14:417-28. doi:10.1038/nri3683

12. Gautier EL, Shay T, Miller J, Greter M, Jakubzick C, Ivanov S, et al. Geneexpression profiles and transcriptional regulatory pathways that underlie the identity and diversity of mouse tissue macrophages. Nat Immunol (2012) 13:1118-28. doi:10.1038/ni.2419 
13. Belz GT, Nutt SL. Transcriptional programming of the dendritic cell network. Nat Rev Immunol (2012) 12:101-13. doi:10.1038/nri3149

14. Miller JC, Brown BD, Shay T, Gautier EL, Jojic V, Cohain A, et al. Deciphering the transcriptional network of the dendritic cell lineage. Nat Immunol (2012) 13:888-99. doi:10.1038/ni.2370

15. Hashimoto D, Miller J, Merad M. Dendritic cell and macrophage heterogeneity in vivo. Immunity (2011) 35:323-35. doi:10.1016/j.immuni.2011.09.007

16. Mildner A, Jung S. Development and function of dendritic cell subsets. Immunity (2014) 40:642-56. doi:10.1016/j.immuni.2014.04.016

17. Shortman K, Naik SH. Steady-state and inflammatory dendritic-cell development. Nat Rev Immunol (2007) 7:19-30. doi:10.1038/nri1996

18. Murphy KM. Transcriptional control of dendritic cell development. Adv Immunol (2013) 120:239-67. doi:10.1016/B978-0-12-417028-5.00009-0

19. Maraskovsky E, Brasel K, Teepe M, Roux ER, Lyman SD, Shortman K, et al. Dramatic increase in the numbers of functionally mature dendritic cells in Flt3 ligand-treated mice: multiple dendritic cell subpopulations identified. $J$ Exp Med (1996) 184:1953-62. doi:10.1084/jem.184.5.1953

20. Maraskovsky E, Pulendran B, Brasel K, Teepe M, Roux ER, Shortman $\mathrm{K}$, et al. Dramatic numerical increase of functionally mature dendritic cells in FLT3 ligand-treated mice. Adv Exp Med Biol (1997) 417:33-40. doi:10.1007/978-1-4757-9966-8_6

21. Karsunky H, Merad M, Cozzio A, Weissman IL, Manz MG. Flt3 ligand regulates dendritic cell development from Flt3+ lymphoid and myeloid-committed progenitors to Flt3+ dendritic cells in vivo. J Exp Med (2003) 198:305-13. doi:10.1084/jem.20030323

22. Naik SH, O’Keeffe M, Proietto A, Hochrein H, Shortman K, Wu L. CD8+, CD8-, and plasmacytoid dendritic cell generation in vitro using flt3 ligand. Methods Mol Biol (2010) 595:167-76. doi:10.1007/978-1-60761-421-0_10

23. Brasel K, De Smedt T, Smith JL, Maliszewski CR. Generation of murine dendritic cells from flt3-ligand-supplemented bone marrow cultures. Blood (2000) 96:3029-39.

24. Gilliet M, Boonstra A, Paturel C, Antonenko S, Xu XL, Trinchieri G, et al. The development of murine plasmacytoid dendritic cell precursors is differentially regulated by Flt3-ligand and granulocyte/macrophage colony-stimulating factor. J Exp Med (2002) 195:953-8. doi:10.1084/jem.20020045

25. McKenna HJ, Stocking KL, Miller RE, Brasel K, De Smedt T, Maraskovsky E, et al. Mice lacking Flt3 ligand have deficient hematopoiesis affecting hematopoietic progenitor cells, dendritic cells, and natural killer cells. Blood (2000) 95:3489-97.

26. Tussiwand R, Onai N, Mazzucchelli L, Manz MG. Inhibition of natural type I IFN-producing and dendritic cell development by a small molecule receptor tyrosine kinase inhibitor with Flt3 affinity. J Immunol (2005) 175:3674-80. doi:10.4049/jimmunol.175.6.3674

27. Manfra DJ, Chen SC, Jensen KK, Fine JS, Wiekowski MT, Lira SA. Conditional expression of murine Flt3 ligand leads to expansion of multiple dendritic cell subsets in peripheral blood and tissues of transgenic mice. J Immunol (2003) 170:2843-52. doi:10.4049/jimmunol.170.6.2843

28. Waskow C, Liu K, Darrasse-Jeze G, Guermonprez P, Ginhoux F, Merad $\mathrm{M}$, et al. The receptor tyrosine kinase Flt3 is required for dendritic cell development in peripheral lymphoid tissues. Nat Immunol (2008) 9:676-83. doi:10.1038/ni.1615

29. Laouar Y, Welte T, Fu XY, Flavell RA. STAT3 is required for Flt3L-dependent dendritic cell differentiation. Immunity (2003) 19:903-12. doi:10.1016/ S1074-7613(03)00332-7

30. Onai N, Obata-Onai A, Tussiwand R, Lanzavecchia A, Manz MG. Activation of the Flt3 signal transduction cascade rescues and enhances type I interferon-producing and dendritic cell development 1. J Exp Med (2006) 203:227-38. doi:10.1084/jem.20051645

31. Rathinam C, Geffers R, Yucel R, Buer J, Welte K, Moroy T, et al. The transcriptional repressor Gfil controls STAT3-dependent dendritic cell development and function. Immunity (2005) 22:717-28. doi:10.1016/j. immuni.2005.04.007

32. Hock H, Hamblen MJ, Rooke HM, Schindler JW, Saleque S, Fujiwara Y, et al. Gfi-1 restrictsproliferation and preservesfunctionalintegrity of haematopoietic stem cells. Nature (2004) 431:1002-7. doi:10.1038/nature02994

33. Karsunky H, Mende I, Schmidt T, Moroy T. High levels of the onco-protein Gfi-1 accelerate T-cell proliferation and inhibit activation induced T-cell death in Jurkat T-cells. Oncogene (2002) 21:1571-9. doi:10.1038/sj.onc.1205216

34. Yucel R, Karsunky H, Klein-Hitpass L, Moroy T. The transcriptional repressor Gfil affects development of early, uncommitted c-Kit+ T cell progenitors and CD4/CD8 lineage decision in the thymus. J Exp Med (2003) 197:831-44. doi:10.1084/jem.20021417

35. Kim W, Klarmann KD, Keller JR. Gfi-1 regulates the erythroid transcription factor network through Id2 repression in murine hematopoietic progenitor cells. Blood (2014) 124:1586-96. doi:10.1182/blood-2014-02-556522

36. Li H, Ji M, Klarmann KD, Keller JR. Repression of Id2 expression by Gfi-1 is required for B-cell and myeloid development. Blood (2010) 116:1060-9. doi:10.1182/blood-2009-11-255075

37. Mackarehtschian K, Hardin JD, Moore KA, Boast S, Goff SP, Lemischka IR. Targeted disruption of the flk $2 / \mathrm{flt} 3$ gene leads to deficiencies in primitive hematopoietic progenitors. Immunity (1995) 3:147-61. doi:10.1016/1074-7613(95)90167-1

38. Adolfsson J, Mansson R, Buza-Vidas N, Hultquist A, Liuba K, Jensen CT, et al. Identification of Flt3+ lympho-myeloid stem cells lacking erythro-megakaryocytic potential a revised road map for adult blood lineage commitment. Cell (2005) 121:295-306. doi:10.1016/j.cell.2005.02.013

39. Wang P, Xue Y, Han Y, Lin L, Wu C, Xu S, et al. The STAT3-binding long noncoding RNA lnc-DC controls human dendritic cell differentiation. Science (2014) 344:310-3. doi:10.1126/science. 1251456

40. Wu Y, Smas CM. Wdnm1-like, a new adipokine with a role in MMP-2 activation. Am J Physiol Endocrinol Metab (2008) 295:E205-15. doi:10.1152/ ajpendo. 90316.2008

41. Tamura T, Tailor P, Yamaoka K, Kong HJ, Tsujimura H, O'Shea JJ, et al. IFN regulatory factor- 4 and -8 govern dendritic cell subset development and their functional diversity. J Immunol (2005) 174:2573-81. doi:10.4049/ jimmunol.174.5.2573

42. Suzuki S, Honma K, Matsuyama T, Suzuki K, Toriyama K, Akitoyo I, et al. Critical roles of interferon regulatory factor 4 in CD11bhighCD8alphadendritic cell development. Proc Natl Acad Sci U S A (2004) 101:8981-6. doi:10.1073/pnas.0402139101

43. Yamamoto M, Kato T, Hotta C, Nishiyama A, Kurotaki D, Yoshinari M, et al. Shared and distinct functions of the transcription factors IRF4 and IRF8 in myeloid cell development. PLoS One (2011) 6:e25812. doi:10.1371/journal. pone. 0025812

44. Williams JW, Tjota MY, Clay BS, Vander LB, Bandukwala HS, Hrusch CL, et al. Transcription factor IRF4 drives dendritic cells to promote Th2 differentiation. Nat Commun (2013) 4:2990. doi:10.1038/ncomms3990

45. Li HS, Yang CY, Nallaparaju KC, Zhang H, Liu YJ, Goldrath AW, et al. The signal transducers STAT5 and STAT3 control expression of Id2 and E2-2 during dendritic cell development. Blood (2012) 120:4363-73. doi:10.1182/ blood-2012-07-441311

46. Jackson JT, Hu Y, Liu R, Masson F, D’Amico A, Carotta S, et al. Id2 expression delineates differential checkpoints in the genetic program of CD8alpha+ and CD103+ dendritic cell lineages. EMBO J (2011) 30:2690-704. doi:10.1038/ emboj.2011.163

47. Nagasawa M, Schmidlin H, Hazekamp MG, Schotte R, Blom B. Development of human plasmacytoid dendritic cells depends on the combined action of the basic helix-loop-helix factor E2-2 and the Ets factor Spi-B. Eur J Immunol (2008) 38:2389-400. doi:10.1002/eji.200838470

48. Cisse B, Caton ML, Lehner M, Maeda T, Scheu S, Locksley R, et al. Transcription factor E2-2 is an essential and specific regulator of plasmacytoid dendritic cell development 1. Cell (2008) 135:37-48. doi:10.1016/j.cell.2008.09.016

49. Spits H, Couwenberg F, Bakker AQ, Weijer K, Uittenbogaart CH. Id2 and Id3 inhibit development of CD34(+) stem cells into predendritic cell (pre-DC)2 but not into pre-DC1. Evidence for a lymphoid origin of pre-DC2. J Exp Med (2000) 192:1775-84. doi:10.1084/jem.192.12.1775

50. Hacker C, Kirsch RD, Ju XS, Hieronymus T, Gust TC, Kuhl C, et al. Transcriptional profiling identifies Id2 function in dendritic cell development. Nat Immunol (2003) 4:380-6. doi:10.1038/ni903

51. Ghosh HS, Cisse B, Bunin A, Lewis KL, Reizis B. Continuous expression of the transcription factor e2-2 maintains the cell fate of mature plasmacytoid dendritic cells. Immunity (2010) 33:905-16. doi:10.1016/j.immuni.2010.11.023

52. Ghosh HS, Ceribelli M, Matos I, Lazarovici A, Bussemaker HJ, Lasorella A, et al. ETO family protein Mtg16 regulates the balance of dendritic cell subsets by repressing Id2. J Exp Med (2014) 211:1623-35. doi:10.1084/ jem.20132121

53. Kashiwada M, Pham NL, Pewe LL, Harty JT, Rothman PB. NFIL3/E4BP4 is a key transcription factor for CD8\{alpha\}+ dendritic cell development. Blood (2011) 117:6193-7. doi:10.1182/blood-2010-07-295873 
54. Onai N, Kurabayashi K, Hosoi-Amaike M, Toyama-Sorimachi N, Matsushima K, Inaba $\mathrm{K}$, et al. A clonogenic progenitor with prominent plasmacytoid dendritic cell developmental potential. Immunity (2013) 38:943-57. doi:10.1016/j.immuni.2013.04.006

55. Liu K, Victora GD, Schwickert TA, Guermonprez P, Meredith MM, Yao K, et al. In vivo analysis of dendritic cell development and homeostasis. Science (2009) 324:392-7. doi:10.1126/science.1170540

56. Kurotaki D, Yamamoto M, Nishiyama A, Uno K, Ban T, Ichino M, et al. IRF8 inhibits C/EBPalpha activity to restrain mononuclear phagocyte progenitors from differentiating into neutrophils. Nat Commun (2014) 5:4978. doi:10.1038/ncomms5978

57. Kueh HY, Champhekar A, Nutt SL, Elowitz MB, Rothenberg EV. Positive feedback between PU.1 and the cell cycle controls myeloid differentiation. Science (2013) 341:670-3. doi:10.1126/science.1240831

58. Heissig B, Hattori K, Dias S, Friedrich M, Ferris B, Hackett NR, et al. Recruitment of stem and progenitor cells from the bone marrow niche requires MMP-9 mediated release of kit-ligand. Cell (2002) 109:625-37. doi:10.1016/S0092-8674(02)00754-7

59. Naik SH, Proietto AI, Wilson NS, Dakic A, Schnorrer P, Fuchsberger M, et al. Cutting edge: generation of splenic CD8+ and CD8- dendritic cell equivalents in Fms-like tyrosine kinase 3 ligand bone marrow cultures. J Immunol (2005) 174:6592-7. doi:10.4049/jimmunol.174.11.6592

60. Naik SH, Metcalf D, van Nieuwenhuijze A, Wicks I, Wu L, O'Keeffe M, et al. Intrasplenic steady-state dendritic cell precursors that are distinct from monocytes. Nat Immunol (2006) 7:663-71. doi:10.1038/ni1340

61. Liu K, Waskow C, Liu X, Yao K, Hoh J, Nussenzweig M. Origin of dendritic cells in peripheral lymphoid organs of mice. Nat Immunol (2007) 8:578-83. doi:10.1038/ni1462

62. Grajales-Reyes GE, Iwata A, Albring J, Wu X, Tussiwand R, Kc W, et al. Batf3 maintains autoactivation of Irf8 for commitment of a CD8alpha(+) conventional DC clonogenic progenitor. Nat Immunol (2015) 16:708-17. doi:10.1038/ni.3197

63. Schlitzer A, Sivakamasundari V, Chen J, Sumatoh HR, Schreuder J, Lum J, et al. Identification of $\mathrm{CDC} 1$ - and $\mathrm{CDC} 2$-committed DC progenitors reveals early lineage priming at the common DC progenitor stage in the bone marrow. Nat Immunol (2015) 16:718-28. doi:10.1038/ni.3200

64. Meredith MM, Liu K, Kamphorst AO, Idoyaga J, Yamane A, Guermonprez $\mathrm{P}$, et al. Zinc finger transcription factor $\mathrm{zDC}$ is a negative regulator required to prevent activation of classical dendritic cells in the steady state. J Exp Med (2012) 209:1583-93. doi:10.1084/jem.20121003

65. Reizis B. Classical dendritic cells as a unique immune cell lineage. J Exp Med (2012) 209:1053-6. doi:10.1084/jem.20121038

66. Satpathy AT, Kc W, Albring JC, Edelson BT, Kretzer NM, Bhattacharya D, et al. Zbtb46 expression distinguishes classical dendritic cells and their committed progenitors from other immune lineages. J Exp Med (2012) 209:1135-52. doi:10.1084/jem.20120030

67. Schraml BU, van Blijswijk J, Zelenay S, Whitney PG, Filby A, Acton SE, et al. Genetic tracing via DNGR-1 expression history defines dendritic cells as a hematopoietic lineage. Cell (2013) 154:843-58. doi:10.1016/j.cell.2013.07.014

68. Hildner K, Edelson BT, Purtha WE, Diamond M, Matsushita H, Kohyama $\mathrm{M}$, et al. Batf3 deficiency reveals a critical role for CD8alpha+ dendritic cells in cytotoxic T cell immunity. Science (2008) 322:1097-100. doi:10.1126/ science. 1164206

69. Edelson BT, Kc W, Juang R, Kohyama M, Benoit LA, Klekotka PA, et al. Peripheral CD103+ dendritic cells form a unified subset developmentally related to CD8alpha+ conventional dendritic cells. J Exp Med (2010) 207:823-36. doi:10.1084/jem.20091627

70. Ginhoux F, Liu K, Helft J, Bogunovic M, Greter M, Hashimoto D, et al. The origin and development of nonlymphoid tissue CD103+ DCs. J Exp Med (2009) 206:3115-30. doi:10.1084/jem.20091756

71. Seillet C, Jackson JT, Markey KA, Hill GR, Macdonald KP, Nutt SL, et al. CD8alpha+ DCs can be induced in the absence of transcription factors Id2, Nfil3 and Batf3. Blood (2013) 121:1574-83. doi:10.1182/ blood-2012-07-445650

72. Tussiwand R, Lee WL, Murphy TL, Mashayekhi M, Wumesh KC, Albring JC, et al. Compensatory dendritic cell development mediated by BATF-IRF interactions. Nature (2012) 490:502-7. doi:10.1038/nature11531

73. Persson EK, Uronen-Hansson H, Semmrich M, Rivollier A, Hagerbrand K, Marsal J, et al. IRF4 transcription-factor-dependent CD103(+)CD11b(+) dendritic cells drive mucosal Thelper 17 cell differentiation. Immunity (2013) 38:958-69. doi:10.1016/j.immuni.2013.03.009

74. Schlitzer A, McGovern N, Teo P, Zelante T, Atarashi K, Low D, et al. IRF4 transcription factor-dependent CD11b(+) dendritic cells in human and mouse control mucosal IL-17 cytokine responses. Immunity (2013) 38:970-83. doi:10.1016/j.immuni.2013.04.011

75. Vander LB, Khan AA, Hackney JA, Agrawal S, Lesch J, Zhou M, et al. Transcriptional programming of dendritic cells for enhanced MHC class II antigen presentation. Nat Immunol (2014) 15:161-7. doi:10.1038/ni.2795

76. Zhou Q, Ho AW, Schlitzer A, Tang Y, Wong KH, Wong FH, et al. CD11b+ lung dendritic cells orchestrate Th2 immunity to Blomia tropicalis. J Immunol (2014) 193:496-509. doi:10.4049/jimmunol.1303138

77. Gao Y, Nish SA, Jiang R, Hou L, Licona-Limon P, Weinstein JS, et al. Control of $\mathrm{T}$ helper 2 responses by transcription factor IRF4-dependent dendritic cells. Immunity (2013) 39:722-32. doi:10.1016/j.immuni.2013.08.028

78. Bajana S, Roach K, Turner S, Paul J, Kovats S. IRF4 promotes cutaneous dendritic cell migration to lymph nodes during homeostasis and inflammation. J Immunol (2012) 189:3368-77. doi:10.4049/jimmunol.1102613

79. Burkly L, Hession C, Ogata L, Reilly C, Marconi LA, Olson D, et al. Expression of relB is required for the development of thymic medulla and dendritic cells. Nature (1995) 373:531-6. doi:10.1038/373531a0

80. Wu L, D'Amico A, Winkel KD, Suter M, Lo D, Shortman K. RelB is essential for the development of myeloid-related CD8alpha- dendritic cells but not of lymphoid-related CD8alpha+ dendritic cells. Immunity (1998) 9:839-47. doi:10.1016/S1074-7613(00)80649-4

81. Caton ML, Smith-Raska MR, Reizis B. Notch-RBP-J signaling controls the homeostasis of CD8- dendritic cells in the spleen. J Exp Med (2007) 204:1653-64. doi:10.1084/jem.20062648

82. Cheng P, Nefedova Y, Miele L, Osborne BA, Gabrilovich D. Notch signaling is necessary but not sufficient for differentiation of dendritic cells. Blood (2003) 102:3980-8. doi:10.1182/blood-2003-04-1034

83. Satpathy AT, Briseno CG, Lee JS, Ng D, Manieri NA, Kc W, et al. Notch2dependent classical dendritic cells orchestrate intestinal immunity to attaching-and-effacing bacterial pathogens. Nat Immunol (2013) 14:937-48. doi:10.1038/ni.2679

84. Tussiwand R, Everts B, Grajales-Reyes GE, Kretzer NM, Iwata A, Bagaitkar J, et al. Klf4 expression in conventional dendritic cells is required for $\mathrm{T}$ helper 2 cell responses. Immunity (2015) 42:916-28. doi:10.1016/j. immuni.2015.04.017

85. Kurotaki D, Osato N, Nishiyama A, Yamamoto M, Ban T, Sato H, et al. Essential role of the IRF8-KLF4 transcription factor cascade in murine monocyte differentiation. Blood (2013) 121:1839-49. doi:10.1182/blood-2012-06-437863

86. Dicken J, Mildner A, Leshkowitz D, Touw IP, Hantisteanu S, Jung S, et al. Transcriptional reprogramming of CD11b+Esam(hi) dendritic cell identity and function by loss of Runx3. PLoS One (2013) 8:e77490. doi:10.1371/ journal.pone.0077490

87. Satpathy AT, Briseño CG, Cai X, Michael DG, Chou C. Hsiung S, et al. Runx1 and $\operatorname{Cbf} \beta$ regulate the development of dendritic cell precursors by restricting granulocyte/macrophage lineages. Blood (2014) 123:2968-77. doi:10.1182/ blood-2013-11-539643

88. Kobayashi T, Walsh PT, Walsh MC, Speirs KM, Chiffoleau E, King CG, et al. TRAF6 is a critical factor for dendritic cell maturation and development. Immunity (2003) 19:353-63. doi:10.1016/S1074-7613(03)00230-9

89. Amit I, Garber M, Chevrier N, Leite AP, Donner Y, Eisenhaure T, et al. Unbiased reconstruction of a mammalian transcriptional network mediating pathogen responses. Science (2009) 326:257-63. doi:10.1126/ science. 1179050

90. Jaitin DA, Kenigsberg E, Keren-Shaul H, Elefant N, Paul F, Zaretsky I, et al. Massively parallel single-cell RNA-seq for marker-free decomposition of tissues into cell types. Science (2014) 343:776-9. doi:10.1126/science.1247651

91. Mildner A, Chapnik E, Manor O, Yona S, Kim KW, Aychek T, et al Mononuclear phagocyte miRNome analysis identifies miR-142 as critical regulator of murine dendritic cell homeostasis. Blood (2013) 121:1016-27. doi:10.1182/blood-2012-07-445999

92. Paul F, Amit I. Plasticity in the transcriptional and epigenetic circuits regulating dendritic cell lineage specification and function. Curr Opin Immunol (2014) 30:1-8. doi:10.1016/j.coi.2014.04.004

93. Lewis KL, Caton ML, Bogunovic M, Greter M, Grajkowska LT, Ng D, et al. Notch2 receptor signaling controls functional differentiation of dendritic 
cells in the spleen and intestine. Immunity (2011) 35:780-91. doi:10.1016/j. immuni.2011.08.013

94. Watchmaker PB, Lahl K, Lee M, Baumjohann D, Morton J, Kim SJ, et al. Comparative transcriptional and functional profiling defines conserved programs of intestinal DC differentiation in humans and mice. Nat Immunol (2014) 15:98-108. doi:10.1038/ni.2768

95. Terry RL, Miller SD. Molecular control of monocyte development. Cell Immunol (2014) 291:16-21. doi:10.1016/j.cellimm.2014.02.008

96. Friedman AD. Transcriptional control of granulocyte and monocyte development. Oncogene (2007) 26:6816-28. doi:10.1038/sj.onc.1210764

97. Hettinger J, Richards DM, Hansson J, Barra MM, Joschko AC, Krijgsveld J, et al. Origin of monocytes and macrophages in a committed progenitor. Nat Immunol (2013) 14:821-30. doi:10.1038/ni.2638

98. Schulz C, Gomez PE, Chorro L, Szabo-Rogers H, Cagnard N, Kierdorf K, et al. A lineage of myeloid cells independent of $\mathrm{Myb}$ and hematopoietic stem cells. Science (2012) 336:86-90. doi:10.1126/science.1219179

99. Ginhoux F, Greter M, Leboeuf M, Nandi S, See P, Gokhan S, et al. Fate mapping analysis reveals that adult microglia derive from primitive macrophages. Science (2010) 330:841-5. doi:10.1126/science.1194637

100. Geissmann F, Manz MG, Jung S, Sieweke MH, Merad M, Ley K. Development of monocytes, macrophages, and dendritic cells. Science (2010) 327:656-61. doi:10.1126/science.1178331

101. Epelman S, Lavine KJ, Beaudin AE, Sojka DK, Carrero JA, Calderon B, et al. Embryonic and adult-derived resident cardiac macrophages are maintained through distinct mechanisms at steady state and during inflammation. Immunity (2014) 40:91-104. doi:10.1016/j.immuni.2013.11.019

102. Guilliams M, De Kleer I, Henri S, Post S, Vanhoutte L, De Prijck S, et al. Alveolar macrophages develop from fetal monocytes that differentiate into long-lived cells in the first week of life via GM-CSF. J Exp Med (2013) 210:1977-92. doi:10.1084/jem.20131199

103. Gomez Perdiguero E, Klapproth K, Schulz C, Busch K, Azzoni E, Crozet L, et al. Tissue-resident macrophages originate from yolk-sac-derived erythro-myeloid progenitors. Nature (2015) 518:547-51. doi:10.1038/nature13989

104. Hoeffel G, Wang Y, Greter M, See P, Teo P, Malleret B, et al. Adult Langerhans cells derive predominantly from embryonic fetal liver monocytes with a minor contribution of yolk sac-derived macrophages. J Exp Med (2012) 209:1167-81. doi:10.1084/jem.20120340

105. Sheng J, Ruedl C, Karjalainen K. Most tissue-resident macrophages except microglia are derived from fetal hematopoietic stem cells. Immunity (2015) 43:382-93. doi:10.1016/j.immuni.2015.07.016

106. Muller PA, Koscso B, Rajani GM, Stevanovic K, Berres ML, Hashimoto $\mathrm{D}$, et al. Crosstalk between muscularis macrophages and enteric neurons regulates gastrointestinal motility. Cell (2014) 158:300-13. doi:10.1016/j. cell.2014.04.050

107. Bain CC, Bravo-Blas A, Scott CL, Gomez Perdiguero E, Geissmann F, Henri $\mathrm{S}$, et al. Constant replenishment from circulating monocytes maintains the macrophage pool in the intestine of adult mice. Nat Immunol (2014) 15:929-37. doi:10.1038/ni.2967

108. Molawi K, Wolf Y, Kandalla PK, Favret J, Hagemeyer N, Frenzel K, et al. Progressive replacement of embryo-derived cardiac macrophages with age. $J$ Exp Med (2014) 211:2151-8. doi:10.1084/jem.20140639

109. Gautier EL, Ivanov S, Lesnik P, Randolph GJ. Local apoptosis mediates clearance of macrophages from resolving inflammation in mice. Blood (2013) 122:2714-22. doi:10.1182/blood-2013-01-478206

110. Chihara T, Suzu S, Hassan R, Chutiwitoonchai N, Hiyoshi M, Motoyoshi $\mathrm{K}$, et al. IL-34 and M-CSF share the receptor Fms but are not identical in biological activity and signal activation. Cell Death Differ (2010) 17:1917-27. doi:10.1038/cdd.2010.60

111. Greter M, Lelios I, Pelczar P, Hoeffel G, Price J, Leboeuf M, et al. Stromaderived interleukin-34 controls the development and maintenance of Langerhans cells and the maintenance of microglia. Immunity (2012) 37:1050-60. doi:10.1016/j.immuni.2012.11.001

112. Wang Y, Szretter KJ, Vermi W, Gilfillan S, Rossini C, Cella M, et al. IL-34 is a tissue-restricted ligand of CSF1R required for the development of Langerhans cells and microglia. Nat Immunol (2012) 13:753-60. doi:10.1038/ni.2360

113. Zhang P, Iwasaki-Arai J, Iwasaki H, Fenyus ML, Dayaram T, Owens BM, et al. Enhancement of hematopoietic stem cell repopulating capacity and self-renewal in the absence of the transcription factor $\mathrm{C} / \mathrm{EBP}$ alpha. Immunity (2004) 21:853-63. doi:10.1016/j.immuni.2004.11.006

114. Zhang DE, Hetherington CJ, Meyers S, Rhoades KL, Larson CJ, Chen HM, et al. CCAAT enhancer-binding protein (C/EBP) and AML1 (CBF alpha2) synergistically activate the macrophage colony-stimulating factor receptor promoter. Mol Cell Biol (1996) 16:1231-40.

115. Gosselin D, Link VM, Romanoski CE, Fonseca GJ, Eichenfield DZ, Spann NJ, et al. Environment drives selection and function of enhancers controlling tissue-specific macrophage identities. Cell (2014) 159:1327-40. doi:10.1016/j. cell.2014.11.023

116. Lavin Y, Winter D, Blecher-Gonen R, David E, Keren-Shaul H, Merad M, et al. Tissue-resident macrophage enhancer landscapes are shaped by the local microenvironment. Cell (2014) 159:1312-26. doi:10.1016/j.cell.2014.11.018

117. Jojic V, Shay T, Sylvia K, Zuk O, Sun X, Kang J, et al. Identification of transcriptional regulators in the mouse immune system. Nat Immunol (2013) 14:633-43. doi:10.1038/ni.2587

118. Haldar M, Kohyama M, So AY, Kc W, Wu X, Briseno CG, et al. Heme-mediated SPI-C induction promotes monocyte differentiation into iron-recycling macrophages. Cell (2014) 156:1223-34. doi:10.1016/j.cell.2014.01.069

119. A-Gonzalez N, Guillen JA, Gallardo G, Diaz M, de la Rosa JV, Hernandez IH, et al. The nuclear receptor LXRalpha controls the functional specialization of splenic macrophages. Nat Immunol (2013) 14:831-9. doi:10.1038/ni.2622

120. Gautier EL, Chow A, Spanbroek R, Marcelin G, Greter M, Jakubzick C, et al. Systemic analysis of PPARgamma in mouse macrophage populations reveals marked diversity in expression with critical roles in resolution of inflammation and airway immunity. J Immunol (2012) 189:2614-24. doi:10.4049/ jimmunol.1200495

121. Tontonoz P, Spiegelman BM. Fat and beyond: the diverse biology of PPARgamma. Annu Rev Biochem (2008) 77:289-312. doi:10.1146/annurev. biochem.77.061307.091829

122. Baker AD, Malur A, Barna BP, Ghosh S, Kavuru MS, Malur AG, et al. Targeted PPAR \{gamma\} deficiency in alveolar macrophages disrupts surfactant catabolism. J Lipid Res (2010) 51:1325-31. doi:10.1194/jlr.M001651

123. Schneider C, Nobs SP, Kurrer M, Rehrauer H, Thiele C, Kopf M. Induction of the nuclear receptor PPAR-gamma by the cytokine GM-CSF is critical for the differentiation of fetal monocytes into alveolar macrophages. Nat Immunol (2014) 15:1026-37. doi:10.1038/ni.3005

124. Gautier EL, Ivanov S, Williams JW, Huang SC, Marcelin G, Fairfax K, et al. Gata6 regulates aspartoacylase expression in resident peritoneal macrophages and controls their survival. J Exp Med (2014) 211:1525-31. doi:10.1084/ jem. 20140570

125. Jenkins SJ, Ruckerl D, Cook PC, Jones LH, Finkelman FD, Van Rooijen $\mathrm{N}$, et al. Local macrophage proliferation, rather than recruitment from the blood, is a signature of TH2 inflammation. Science (2011) 332:1284-8. doi:10.1126/science.1204351

126. Rosas M, Davies LC, Giles PJ, Liao CT, Kharfan B, Stone TC, et al. The transcription factor Gata6 links tissue macrophage phenotype and proliferative renewal. Science (2014) 344:645-8. doi:10.1126/science.1251414

127. Becher B, Schlitzer A, Chen J, Mair F, Sumatoh HR, Teng KW, et al. Highdimensional analysis of the murine myeloid cell system. Nat Immunol (2014) 15:1181-9. doi:10.1038/ni.3006

128. Naik SH, Perie L, Swart E, Gerlach C, van Rooij N, de Boer RJ, et al. Diverse and heritable lineage imprinting of early haematopoietic progenitors. Nature (2013) 496:229-32. doi:10.1038/nature12013

Conflict of Interest Statement: The authors declare that the research was conducted in the absence of any commercial or financial relationships that could be construed as a potential conflict of interest. The Guest Associate Editor Martin Guilliams declares that, despite having published one manuscript together with Roxane Tussiwand, the review process was handled objectively.

Copyright $\odot 2015$ Tussiwand and Gautier. This is an open-access article distributed under the terms of the Creative Commons Attribution License (CC BY). The use, distribution or reproduction in other forums is permitted, provided the original author(s) or licensor are credited and that the original publication in this journal is cited, in accordance with accepted academic practice. No use, distribution or reproduction is permitted which does not comply with these terms. 